\title{
BIOLOGY
}

\section{Growth, sexual maturity and sexual dimorphism of Aegla georginae (Decapoda: Anomura: Aeglidae) in a tributary of the Ibicuí River in southern Brazil}

\section{Carlos Eduardo Copatti ${ }^{* *}$, Rosemari Parise Legramanti ${ }^{2}$, André Trevisan $^{3} \&$ Sandro Santos ${ }^{2}$}

\begin{abstract}
1 Programa de Pós-Graduação em Biodiversidade Animal, Instituto de Biologia, Universidade Federal da Bahia. Rua Barão de Geremoabo 147, Campus de Ondina, 40170-290 Salvador, BA, Brazil.

2 Programa de Pós-Graduação em Biodiversidade Animal, Universidade Federal de Santa Maria. Avenida Roraima 1000, Camobi, 97105-900 Santa Maria, RS, Brazil.Email: roselegramanti@yahoo.com.br; sandro.santos@ufsm.br ${ }^{3}$ Departamento de Ciências Biológicas, Universidade Alto Vale do Rio do Peixe. Rua Victor Baptista Adami 800, Centro, 89500-000 Caçador, SC, Brazil. Email: trevisan_andre@yahoo.com.br *Corresponding author. E-mail: carloseduardocopatti@yahoo.com.br
\end{abstract}

\begin{abstract}
This study aimed to estimate the growth and size at the onset of sexual maturity in a population of Aegla georginae. Specimens were sampled from November 2007 to October 2008 in the Perau Creek (Ibicuí-Mirim sub-basin; Uruguay River basin). All captured specimens were sexed, and their cephalothoracic length (CL), minor and larger propodi length (MPL, $\mathrm{LPL}$, respectively), height of major chela (HMQ), and abdomen width (AW) were measured. The lengthwise growth of males and females was evaluated using the Bertalanffy model, and the morphological sexual maturity was evaluated using the REGRANS program. The smallest ovigerous female presented a $10.45 \mathrm{~mm}$ CL. Males reached larger sizes than did females, but the growth rate was similar between the sexes. Longevity estimates for males and females were 670 and 736 days, respectively. The best relationship used to infer the size at morphological sexual maturity in males was CLxHMQ (12.78 mm) and in females was CLxAW (10.78 mm). Aegla georginae follows a common pattern for aeglids in terms of lifecycle, where sexual dimorphism is associated with the onset of morphological sexual maturity.
\end{abstract}

KEY WORDS. Age estimative, Bertalanffy, longevity, size at onset maturity.

Species of Aegla Leach, 1820 have a lifecycle that is entirely restricted to freshwater environments and is the only taxon of Anomura with this profile (Bond-Buckup et al. 2008, Fernandes et al. 2013). This genus is composed of over 70 described species with distributions restricted to subtropical South America (SANTOS et al. 2013).

Previous studies have contributed to the understanding of the population dynamics (i.e., longevity, recruitment, allometry, growth rates, juvenile cohort) in species such as Aegla platensis Schmitt, 1942 (Bueno et al. 2000); Aegla castro Schmitt, 1942 (Swiech-Ayoub \& Masunari 2001); Aegla leptodactyla Buckup \& Rossi, 1977 (Noro \& Buckup 2003); Aegla jarai Bond-Buckup \& Buckup, 1994 (Boss et al. 2006); Aegla longirostri Bond-Buckup \& Buckup, 1994 (Silva-Castiglioni et al. 2006); Aegla italacomiensis Bond-Buckup \& Buckup, 1994 (Silva-GonÇAlves et al. 2009); and Aegla manuinflata Bond-Buckup \& Santos, 2009 (Trevisan \& SANTos 2011).
Body growth can be represented by a curve that corresponds to the dimensions of an individual measured over time or, more often, by means of the partial or total population (Margalef 1977). This curve is of great importance because it provides information regarding the maximum size, the age when this size is achieved and the growth rate of individuals (VALENTI et al. 1987).

Additionally, data on the growth and the size at onset of sexual maturity are important to understand the reproductive biology and population in aeglids (Bueno \& SHIMizu 2008, CoPATTI et al. 2015). According to Hartnoll $(1982,2001)$ allometric growth is useful for estimating sexual maturity, because second pleomere width and cheliped dimensions exhibit different growth rates according to the state of maturity. Additionally, the greater cephalothorax width in females and cephalothorax length in males, respectively, can characterise sexual dimor- 
phism in aeglids (BARRía et al. 2014). Sexual dimorphism in the width of the abdomen is not found in other groups of Anomura (Trevisan et al. 2012).

In recent years, some studies have investigated aspects of reproductive biology in aeglids, highlighting aspects of gonadal development (SoкоLowicz et al. 2006), macroscopic and histological analyses of the gonads (SokoLowicz et al. 2007) and morphological, physiological and functional sexual maturity (Bueno \& Shimizu 2009). Furthermore, Viau et al. (2006), Oliveira \& Santos (2011), Trevisan \& Santos (2012) and CopatTi et al. (2015) developed studies that focused on the size at the onset of morphological sexual maturity in aeglids based on the relative growth of body parts, demonstrating the importance of morphological variations in sexual maturity.

Considering the importance of body growth and the onset of morphological sexual maturity for understanding aeglid biology, we propose to study these parameters in Aegla georginae Santos \& Jara, 2013, a threatened species (endangered) of southern Brazil (SANTOS et al. 2013). Additionally, we provide information on differences in size and sexual maturity between the sexes, sexual dimorphism and lifecycle of A. georginae.

\section{MATERIAL AND METHODS}

Field investigations were conducted in the Perau Creek,

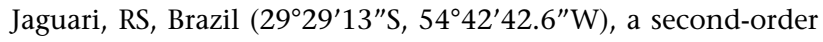
river located in the Jaguari River micro-basin. The stretch of stream in the study is located on the southern boundary of the Atlantic, a region of ecotone with the Pampa biome. The Jaguari River microbasin belongs to the Ibicuí River sub-basin, corresponding to the largest sub-basin of the Uruguay River. The Jaguari River has its mouth in the upper Ibicuí River, and its tributaries are fast streams, creating valleys with rocky outcrops (CopATti et al. 2009).

Margins of the study stretch show remnants of the original deciduous forest interspersed with grass patches, with low anthropic use in the surrounding lands. The river bottom is mainly stony but also consists of sand, gravel, clay, and leaves. The river has an average width of $3 \mathrm{~m}$ and a depth of $15-45 \mathrm{~cm}$.

Physiochemical parameters of the water were measured monthly. Dissolved oxygen (6.00-8.55 mg. $\mathrm{L}^{-1} \mathrm{O}_{2}$ ) and temperature $\left(10.0-22.5^{\circ} \mathrm{C}\right.$ ) were measured using a YSI oximeter (model Y5512), $\mathrm{pH}(6.0-7.5)$ was measured using the $\mathrm{pH}$ meter Quimis (model 400.A), and alkalinity (24-3545 mg.L $\left.{ }^{-1} \mathrm{CaCO}_{3}\right)$, hardness (15-20 $\left.45 \mathrm{mg} . \mathrm{L}^{-1} \mathrm{CaCO}_{3}\right)$, and total ammonia (0.01-0.08 N-NH$)_{3}$ were monitored using a water analysis kit (Alfakit, Florianópolis, Brazil).

Monthly samplings were performed from November 2007 to October 2008 in a section of the stream that is approximately $30 \mathrm{~m}$ in length. Specimens were captured using 25 plastic traps with beef liver randomly set along the sampling zone, and all traps were set late in the afternoon and checked for aeglid individuals the following morning. An additional effort (30 min) was conducted with a hand net (Surber sampler, $0.1 \mathrm{~m}^{2}$ area,
$250 \mu \mathrm{m}$ mesh net) by two researchers for each monthly sampling. Specimens were collected according to permits granted by appropriate agencies (SISBIO process 14180-1).

The following body dimensions of individuals were measured using a digital caliper to the nearest $0.01 \mathrm{~mm}$ : cephalothorax length (CL) (from the tip of the rostrum to the posterior margin of the cephalothorax); cephalothorax width (CW) (distance between the bases of the epibranchial spines); second abdominal somite width (AW); minor propodus length (MPL); larger propodus length (LPL); and height of major chela (HMQ) (Fig. 1). After the measurements, the specimens were returned to the collection location.

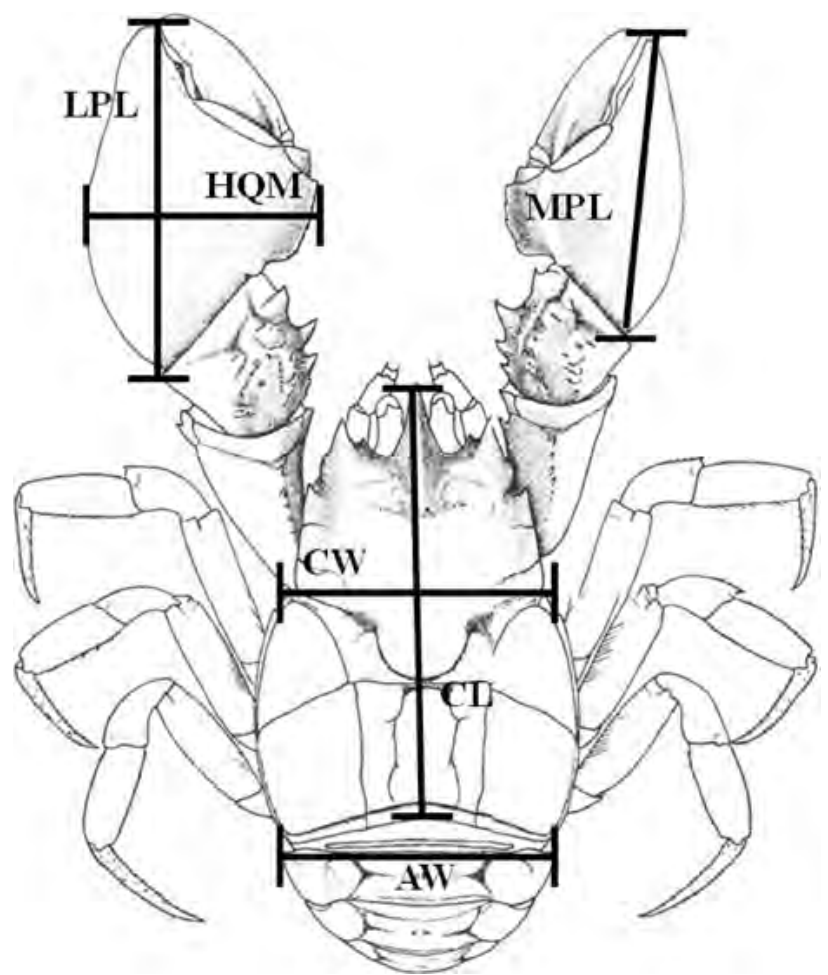

Figure 1. Aegla georginae body dimensions. $\mathrm{CL}$, cephalothorax length; $\mathrm{CW}$, cephalothorax width; $\mathrm{AW}$ : second abdominal somite width; MPL, minor propodus lenght; LPL, larger propodus length; HMQ: height of the major chela. Adapted from SANTOS et al. (2013).

Analysis of the growth in length of A. georginae was performed based on the distribution of the absolute frequencies of size class intervals of $1.00 \mathrm{~mm} \mathrm{CL}$, equivalent to one fourth of the standard deviation calculated for the total sample examined. Individuals with less than $3.00 \mathrm{~mm}$ CL were considered unsexed juveniles because their pleopods and genital pores were too undeveloped to provide reliable identification of the animals' sex and were added to both sexes in the analysis of the frequency distribution of size classes. 
The increase in length was estimated separately in males and females by means of the displacement of the modal frequencies obtained during the sampling of each month, in accordance with the size class frequency distributions (MACDONALD 1987). Modal values of the CL frequency distribution were calculated according to SPIEgel (1979): Mode $=\mathrm{L}_{1}+\left[\Delta_{1} / \Delta_{1}+\Delta_{2}\right]$ C, where: L1 = the inferior limit of the modal class; $\Delta_{1}$ = excess of modal frequency/inferior class; $\Delta_{2}=$ excess of modal frequency/superior class and; $\mathrm{C}=$ the amplitude of the modal class interval. BERTALANFFY's (1938) model was used for the CL curve growth: $\mathrm{Ct}=\mathrm{L} \infty\left[1-\mathrm{e}^{-\mathrm{k}\left(\mathrm{t}+\mathrm{t}_{0}\right)}\right]$, where: $\mathrm{Ct}=$ median CL of aeglids at age $\mathrm{t}$ $(\mathrm{mm}) ; \mathrm{L} \infty=$ maximum mean cephalotorax length, in $\mathrm{mm} ; \mathrm{k}$ $=$ age-specific growth rate; $\mathrm{e}=$ natural logarithms; $\mathrm{t}=$ age in days, and to $=$ the parameter related $t_{0}$ the size of the aeglids at birth. The growth curves obtained for males and females were linearised using the method Allen (1976) proposed, and those of males and females were compared using a covariance analysis (ANCOVA; $\alpha=5 \%$ ) (ZAR 1996).

Relative growth patterns of males and females, according to the characteristics of the growth model for each sex, were assessed after an initial adjustment of dispersion points using REGRANS software (PEzzUTo 1993). We used the power equation $\mathrm{y}=\mathrm{ax}^{\mathrm{b}}$ to describe the relative growth of $A$. georginae. Equation was linearised $(\log \mathrm{y}=\log \mathrm{a}+\mathrm{b} \log \mathrm{x})$, and the cephalothorax length (CL) was used as the independent variable (x), related to the other bodily dimensions, which were the dependent variables (y). For this analysis, we used only the dimensions of chelipeds for males and the abdomen for females because these dimensions are considered secondary sexual characteristics in pleocyemate decapods; moreover, development of these structures is associated with a shift between phases in the lifecycle (HarTNOlL 1982).

The coefficient of allometric growth (b) of the equation expresses the analogy between the parts evaluated. We used a Student's t-test to verify whether the growth was positive or negative allometric (statistically above or below 1.00, respectively) or isometric growth (statistically similar to 1.00). Furthermore, the intercept of the linear growth of male and female juveniles and adults was evaluated. These analyses were performed using an analysis of covariance (ANCOVA) with a confidence interval of 95\% (SOKAL \& ROHLF 1979).

For assessment of sexual dimorphism, the animals were divided into four categories according to size at morphological sexual maturity (see Results): juvenile males, adult males, juvenile females, and adult females. All measurements taken in the field were log-transformed to normalise the data. All aeglids measurements were standardised by applying the formula $\mathrm{Yi}^{*}=\mathrm{Yi}(\mathrm{X})$ $\mathrm{Xi})^{\mathrm{b}}$, where: $\mathrm{Yi}^{*}=$ standardised measurement of the length of specimen $\mathrm{i}$; $\mathrm{Y}$ = measurement of the dimension of the specimen to be standardised; $\mathrm{Xi}=$ cephalothorax length of specimen $\mathrm{i} ; \mathrm{X}=$ mean value of $\mathrm{CL}$ of specimens examined; and $\mathrm{b}=$ exponent of the allometric equation $\mathrm{Y}=\mathrm{ax}$. An ANOVA was used to compare all dimension measures of various categories (ZAR 1996).

\section{RESULTS}

A total of 1774 individuals were measured: 1259 males, 512 females and three non-sexed juveniles. CL of the males and females, ranged from 3.11 to $26.00 \mathrm{~mm}$ and from 3.73 to 22.36 $\mathrm{mm}$, respectively. We recorded 119 ovigerous females, with 112 reaching this phase during autumn (60, 39 and 13 in March, April and May, respectively). In addition, between June and September, one or two ovigerous females were recorded per month. CL of the ovigerous female ranged from 10.45 to $19.38 \mathrm{~mm}$.

Recruiting was detected beginning in March 2008, at the end of the summer season. However, juveniles were sampled in all seasons of the year for both sexes, according to the distribution of absolute frequencies of CL (Figs. 2-3).

Regarding the sexual dimorphism of $A$. georginae, no significant differences were observed between the bodily dimensions of male and female juveniles ( $\mathrm{p}>0.05)$; however, significant differences were found between male and female adults $(\mathrm{p}<$ $0.05)$. All dimensions of adult males were higher than those of adult females $(\mathrm{p}<0.05)$.

The estimated value of the average maximum cephalothorax size $(\mathrm{L} \infty)$ through the growth curve was 26.57 and $21.71 \mathrm{~mm}$ for males and females, respectively (Figs. 4-5). These values are close to the record for the largest animals found in field: 26.00 and $21.90 \mathrm{~mm}$ CL for males and females, respectively. Males reached greater CL than did females, but the growth rate was similar between the sexes $(\mathrm{k}=0.0064$ and 0.0080 for males and females, respectively). Longevity estimated through the analyses of the growth curve was higher in females (736 days) than in males (670 days).

Analyses of body relationships of A.georginae showed that the measures of chelipeds in males and AW in females are effective for estimating the size of the onset of morphological sexual maturity (Figs. 6-9). Evaluations of elevations and intercepts of the linear models of juvenile and adult males allowed for the estimation of the inflection point at $12.78 \mathrm{~mm}$ for the CLxHMQ relationship. In females, the CLxAW relationship showed an inflection point at $10.78 \mathrm{~mm}$ (Table 1). These relationships indicate morphological sexual maturity because they have values that approach the size of the smallest ovigerous female found in field (10.45 mm CL). So, A. georginae adult females can become ovigerous in March (beginning of the reproductive period), regardless of their CL.

During the ontogeny of $A$.georginae, relationship between the body parts had different allometric coefficients. In males, all the relationships of cheliped dimensions showed positive allometry. In females, in turn, the CLxAW relationship showed positive allometry for adults, while in juveniles allometry was negative (Table 1). In all male and female data groups, secondary sexual characteristics showed different growth patterns before and after the onset of morphological sexual maturity because the values of the intercepts (a) and slopes (b) were different according to ANCOVA $(\mathrm{p}<0.01)$ (Table 2$)$. 

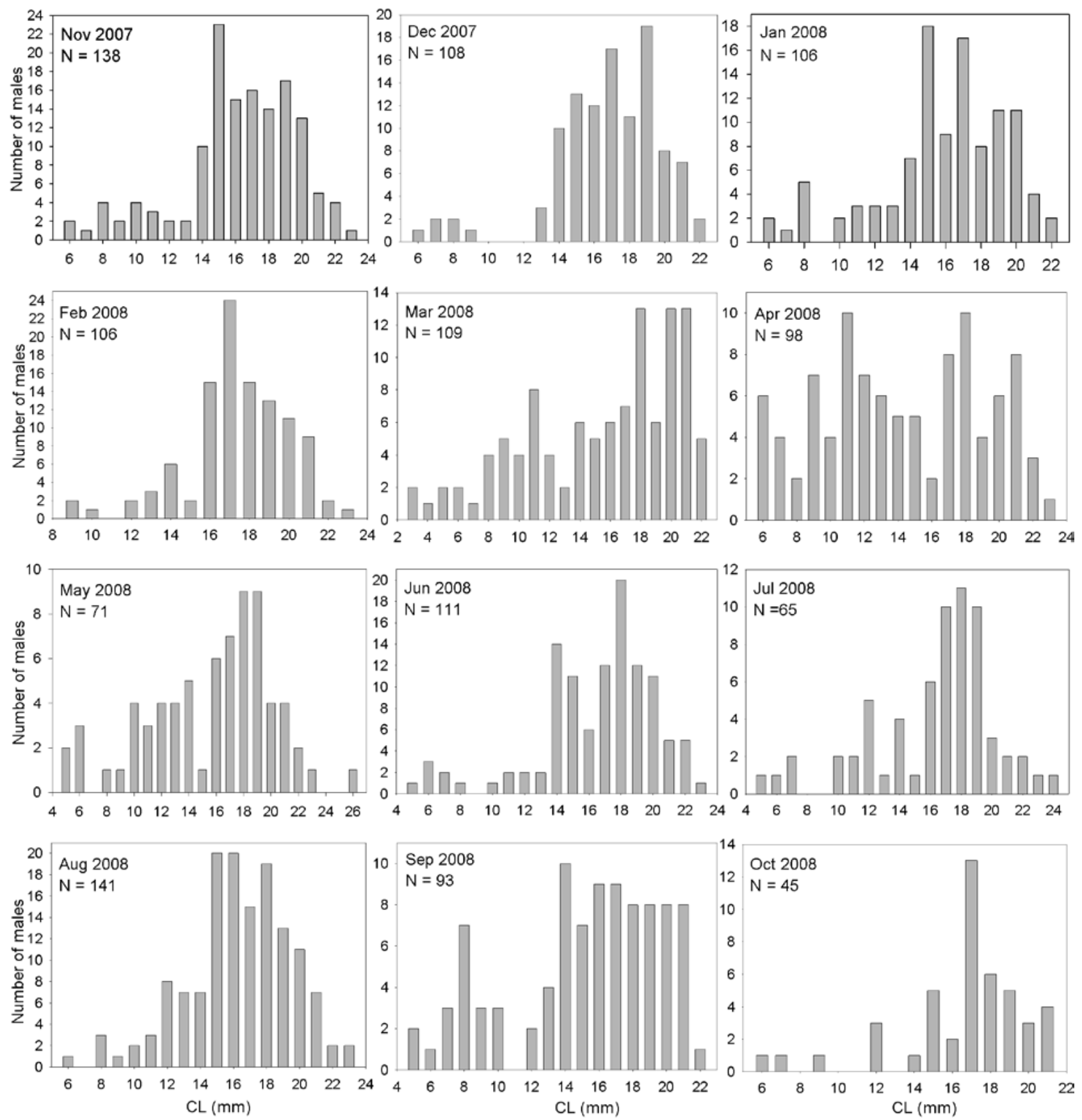

Figure 2. Absolute frequency distribution of cephalothoracic length $(\mathrm{CL})(\mathrm{mm})$ classes of Aegla georginae males, Perau Creek, Ibicuí Basin, Brazil.

\section{DISCUSSION}

The impact of seasonality on recruitment and reproduction in aeglids is not yet clear. For example, flood pressure could severely affect juveniles since they are more susceptible to being washed-out to less favourable areas (Bueno et al. 2014). Possibly, regional and latitudinal factors are involved, and those from rivers at low latitudinal regions have shown a marked seasonal reproductive pattern (Bueno \& Shimizu 2008, Bueno et al. 2014). Aegla georginae juveniles were sampled in all seasons of the 

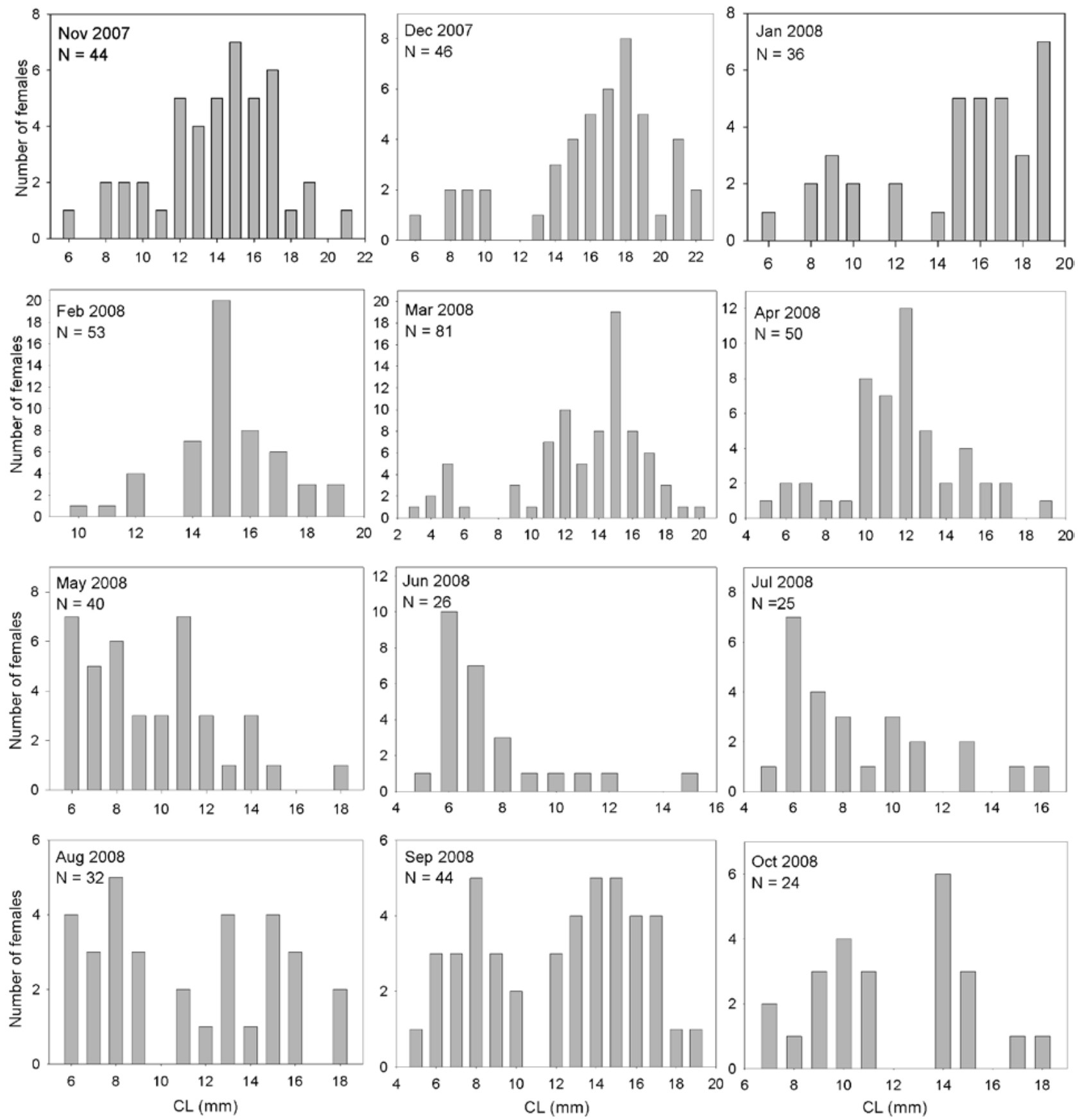

Figure 3. Absolute frequency distribution of cephalothoracic length $(\mathrm{CL})(\mathrm{mm})$ classes of Aegla georginae females, Perau Creek, lbicuí Basin, Brazil.

year, but ovigerous females were more abundant in autumn and juveniles might have originated mainly from spawning occurred during this season. In addition, records of the few ovigerous females during winter and early spring may be viewed as possible isolated cases of late oviposition and also contributing to lower rates of registered juveniles throughout the year. According to Tudge (2003), the timing of spawning differs between species and between populations of the same species. Thus, A. georginae could potentially breeds from March to September.

The higher concentration of juveniles in March might be 
Table 1. Allometric relationships of the populations of Aegla georginae in the PerauCreek, lbicuí Basin, Brazil. (JM) Juvenile males, (AM) adult males, (JF) juvenile females, (AF) adult females, (CL) cephalothorax length, (AW) second abdominal somite width, (MPL) minor propodus length, (LPL) larger propodus length, (HMQ) height of major chela, $(+)$ positive allometry, (-) negative allometry, $\left({ }^{*}\right)$ significant.

\begin{tabular}{|c|c|c|c|c|c|c|c|c|}
\hline Variable & Category & Inflection point (mm CL) & Intercept (a) & Declivity (b) & Linear equation $\log y=\log _{a}+b^{\circ} \log _{x}$ & $\mathrm{R}^{2}$ & All & $\mathrm{t}$ test $(\mathrm{b}=1)$ \\
\hline \multirow[t]{2}{*}{ AW } & $\mathrm{FJ}$ & 10.78 & 0.18 & 0.98 & $\log A W=0.18+0.98 \log C L$ & 0.91 & - & $38.62^{*}$ \\
\hline & $\mathrm{AF}$ & & 0.25 & 1.08 & $\log A W=0.25+1.08 \log C L$ & 0.92 & + & $59.76^{*}$ \\
\hline \multirow[t]{2}{*}{ MPL } & JM & 14.54 & 0.47 & 1.12 & $\log M P L=0.47+1.12 \log C L$ & 0.93 & + & $51.36^{*}$ \\
\hline & AM & & 0.95 & 1.55 & $\log M P L=0.95+1.55 \log C L$ & 0.88 & + & $51.33^{*}$ \\
\hline \multirow[t]{2}{*}{ LPL } & JM & 13.90 & 0.42 & 1.12 & $\log L P L=0.42+1.12 \log C L$ & 0.92 & + & $47.67^{*}$ \\
\hline & AM & & 1.06 & 1.69 & $\log L P L=1.06+1.69 \log C L$ & 0.82 & + & $60.43^{*}$ \\
\hline \multirow[t]{2}{*}{ HMQ } & JM & 12.78 & 0.89 & 1.33 & $\log \mathrm{HMQ}=-0.05+1.33 \log \mathrm{CL}$ & 0.95 & + & $34.02^{*}$ \\
\hline & AM & & 1.45 & 1.84 & $\log H M Q=0.16+1.84 \log C L$ & 0.95 & + & $67.12^{*}$ \\
\hline
\end{tabular}

Table 2. Summary of comparisons between the straight lines of Aegla georginae juveniles and adults in the Perau Creek, Ibicuí Basin, Brazil. (M) Male, (F) female, (CL) cephalothorax length, (AW) second abdominal somite width, (MPL) minor propodus length, (LPL) larger propodus length, (HMQ) height of major chela.

\begin{tabular}{cccccc}
\hline Sex & Relationship & F Intercept & F slope & $\alpha$ Intercept & $\alpha$ slope \\
\hline M & CL X MPL & 356.60 & 2832.27 & $<0.0001$ & $<0.0001$ \\
M & CL X LPL & 523.50 & 360.00 & $<0.0001$ & $<0.0001$ \\
M & CL X HMQ & 162.70 & 166.86 & $<0.0100$ & $<0.0100$ \\
F & CL X AW & 5.87 & 9.47 & 0.0100 & $<0.0100$ \\
\hline
\end{tabular}

related to the intense reproductive peak of this species during this period. This pattern is consistent with previous studies, in which aeglids have a single pulse of recruitment per year, as described for Aegla laevis laevis Latreille, 1818 (BAHAMONDE \& Lopez 1961); Aegla paulensis Schmitt, 1942 (Lopez 1965); Aegla perobae Hebling \& Rodriguez, 1977 (Rodrigues \& Hebling 1978); A. platensis (Bueno et al. 2000); A. leptodactyla (Noro \& Buckup 2003); A. jarai (Boss JR et al. 2006); and A. longirostri (SILVA-CASTIGLIONI et al. 2006). In contrast, recruitment throughout the year was described by Trevisan \& Santos (2011) for A. manuinflata, Chiquetto-Machado et al. (2015) for A. schmitti Hobbs, 1978 and CopatTi et al. (2015) for three sympatric aeglids, A. platensis, Aegla grisella Bond-Buckup \& Buckup, 1994 and Aegla ludwigi Santos \& Jara, 2013.

In this study, we verified that asymptotic growth differs between the sexes and Aegla georginae males reached larger sizes than did females. The larger size of males compared to females is a common dimorphic trait in pleocyemate decapods (HaRTNOLL 1974). The size of males might be advantageous during potential intraspecific competition for reproduction (Ayres-Peres et al. 2011, Grabowski et al. 2013). According to Siqueira et al. (2013), female preference for larger males may be one factor related to the evolution of sexual dimorphism.

Furthermore, this pattern was also observed for A. laevis laevis (BAHAMONDE \& LoPEZ 1961); A. paulensis (Lopez 1965); A. perobae (Rodrigues \& Hebling 1978); A. platensis (Bueno \&
Bond-Buckup 2000); A. castro (Swiech-Ayoub \& Masunari 2001); A. leptodactyla (Noro \& Buckup 2003); A. longirostri (Colpo et al. 2005); Aegla fransiscana Buckup \& Rossi, 1977 (SilvA-GonÇALVES et al. 2006); A. itacolomiensis (SILVA-GonÇALVES et al. 2009); $A$. manuinflata (Trevisan \& SANTOS 2012); Aegla parana Schmitt, 1942 (Grabowski et al. 2013); and A. platensis and A. grisella (Copatti et al. 2015), which corroborate our observations. On the other hand, $A$. platensis appears to be an exception, where females showed a larger asymptotic size than did males (BuENo et al. 2000, DaLosto et al. 2014).

Females invest a significant amount of energy in reproductive functions and do not molt during egg incubation, whereas males do not have this limitation, reaching larger sizes compared to females (HARTNOLL 1974). Moreover, reduction in growth can be related to stress resulting from egg laying (Swiech-Ayoub \& Masunari 2001). In females, a tradeoff between energy and growth is given, where the energy supply devoted to reproduction does not allow for a level of growth that is similar to that of males.

In terms of longevity, females tend to live slightly longer than do males (DA SILVA et al. 2016). Males demonstrate aggressive playing behavior (Ayres-PEREs et al. 2011, CoHEN et al. 2011, Trevisan \& SANTos 2014) and remain exposed for a longer period of time on the surface to feed, dispute and court females and thus would be exposed to predation and environmental adversity, reducing their lifespans (SiLva-Castiglioni et al. 2006, Silva-Gonçalves et al. 2009). Under laboratory conditions, males tend to show higher levels of locomotor activity, frequently moving from one place to another (TEODósIo \& MasunARI, 2009); hence they might be under greater risk of predation than are females, which could shorten their lifespan. Indeed, A. georginae females (736 days) presented superior longevity compared to males (670 days). Greater longevity for females was also reported by Silva-Castiglioni et al. (2006) for A. longirostri, Silva-GonÇalves et al. (2009) for A. itacolomiensis and ChIQUETTO-MaChado et al. (2015) for A. schmitti.

On the other hand, BAHAMONDE \& LoPez (1961) and TREvisAN $\&$ SANTOS (2011) observed superior longevity for males compared 

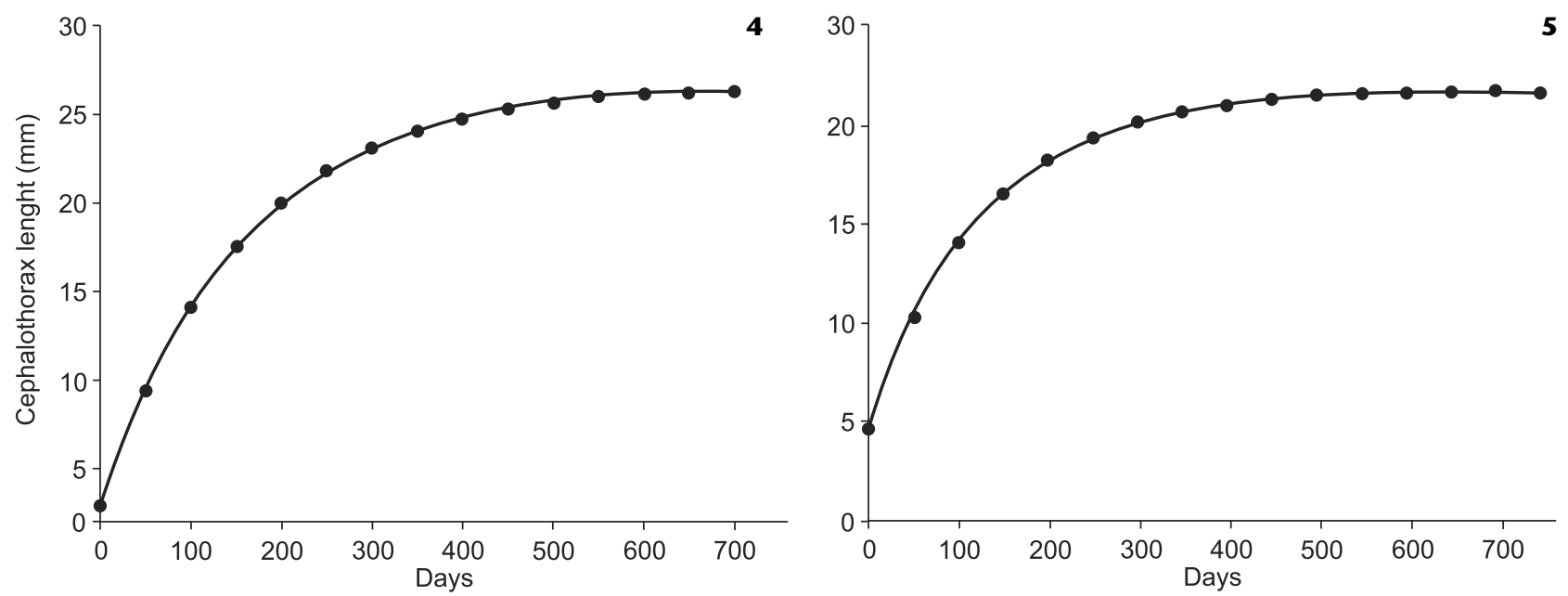

Figures 4-5. Growth curve of cephalothoracic length (CL) ( $\mathrm{mm}$ ) in Aegla georginae males (4) and females (5), Perau Creek, Ibicuí Basin, Brazil. The following equations were fitted to the date: $A: C t=26.57\left[1-e^{-0.0064(t+18.14)}(n=1259 ; r=0.93) ; B: C t=21.71\left[1-e^{-0.008(t+30.25)}\right.\right.$ $(\mathrm{n}=512 ; \mathrm{r}=0.94)$. Where $\mathrm{Ct}=$ cephalothorax length in the time $\mathrm{t} ; \mathrm{t}=$ time in days.
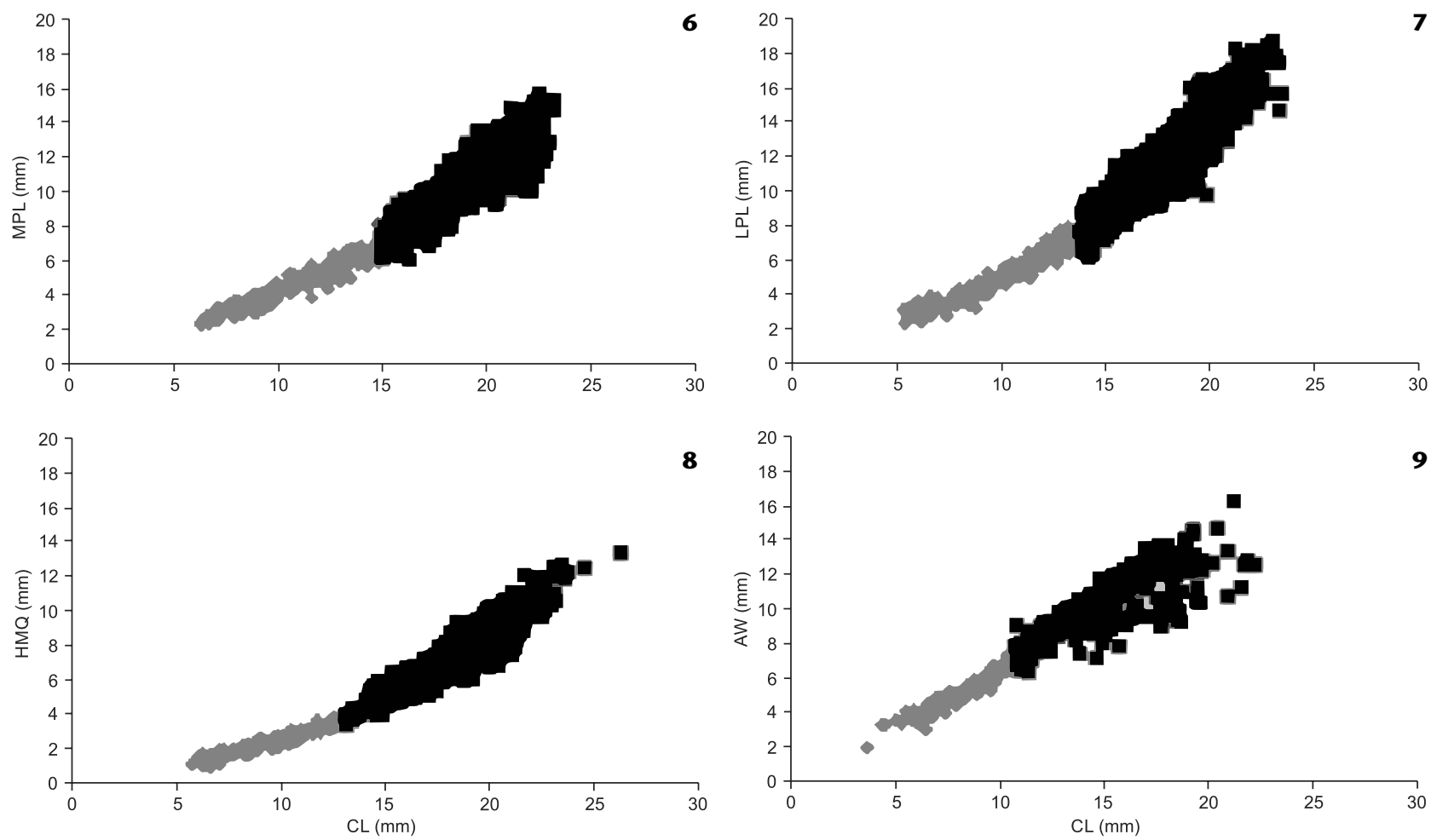

Figures 6-9. Dispersion diagrams that analyse the morphological sexual maturity of Aegla georginae in Perau Creek, Ibicuí Basin, Brazil. (6-8) Males: (6) CLxMPL, $\mathrm{n}=$ 972; (7) CLxLP, $\mathrm{n}=$ 951; (8) CLxHMQ, $\mathrm{n}=$ 915; (9) females, CLxAW, $\mathrm{n}=$ 976. Dark points = adults, Grey points $=$ juveniles.

to females for A. laevis and A. manuinflata, respectively. A variety of patterns for the longevity of aeglids available in the literature (BAHAMONDE \& LOPEZ 1961, SiLVA-CASTIGLIONI et al. 2006,
Silva-Gonçalves et al. 2009, Trevisan \& Santos 2011) shows that the lifecycle of males and females depends on the relationship of physiological systems with external factors. 
In addition to longevity, size at the onset of sexual maturity in aeglids can vary in both males and females. Secondary sexual characteristics are those directly related to mating or hatching eggs (Copatri et al. 2015). Thus, the use of chelae in males occurs in cohort rituals, fighting for females, mating and in the place of establishment (Ayres-Peres et al. 2011, Cohen et al. 2011, PAlaoro et al. 2014). Allometric growth of the chelipeds is generally positive in males and is highly variable in females (TrevisAn et al. 2012).

Likewise, in females, in turn, the CLxAW relationship showed negative allometry in juveniles and positive allometry in adults. In females, the size of the abdomen increases when they are sexually mature, in addition to being a secondary sexual characteristic (HARTNOLL 1982, 2001). In females, increased AW can be attributed to adaptation for reproductive functions, like internal space for the ovaries during the gonadal cycle, and for parental care of embryos and juveniles under the pleon (Sокоцоwicz et al. 2006, 2007).

Colpo et al. (2005), Viau et al. (2006), TREvisan \& SANTos (2012) and CopatTr et al. (2015) found that AW in females and propodus chelae in males showed a change in the growth rate from juvenile to adult for A. longirostri, Aegla uruguayana Schmitt, 1942, A. manuinflata and tree sympatric aeglids (A. platensis, $A$. grisella and $A$. ludwigi), respectively. These findings are in agreement with our data.

In conclusion, A. georginae follows a common pattern for aeglids in terms of lifecycle, growth and sexual maturity, where males are larger compared to females and AW (in females) and chelipeds (in males) are key secondary sexual characteristics defining the onset of morphological sexual maturity. Our results indicate that morphological differences are associated with sex, because sexual dimorphism is associated with the onset of morphological sexual maturity. The onset of sexual maturity of A. georginae is estimated as the point at which changes occur in all dimensions of the animal's body, since male and female juveniles grow similarly up to the point of reaching the adult phase (HARTNOLL 1982). Additionally, considering that A.georginae is a threatened species and has only recently been described, aspects of its biology such as the short reproductive period may be related to difficulties in population recovery. This knowledge is useful for its preservation and understanding its life history.

\section{ACKNOWLEDGEMENT}

We would like to thank CNPq for the productivity grant for SS (311142/2014-1).

\section{LITERATURE CITED}

ALLEN RL (1976) Method for comparing fish growth curves. New Zealand Journal of Marine and Freshwater Research 10: 687-692.

Ayres-Peres L, Araújo PB, Santos S (2011) Description of the agonistic behavior of Aegla longirostri (Decapoda: Aeglidae). Journal of Crustacean Biology 31: 379-388.
BAHAMONDE N, Lopez MT (1961) Estudios biologicos en la populacion de Aegla laevis laevis (Latreille) de el Monte (Crustacea, Decapoda, Anomura). Investigaciones Zoológicas Chilenas 7: 19-58.

Barría EM, Santos S, JARA CG, Butler CJ (2014) Sexual dimorphism in the cephalothorax of freshwater crabs of genus Aegla Leach from Chile (Decapoda, Anomura, Aeglidae): an interspecific approach based on distance variables. Zoomorphology 133: 379-389.

Bertalanffy L (1938) A quantitative theory of organic growth. Human Biology 10: 181-213.

Bond-Buckup G, Shimizu CJ, Pérez-Losada M, Buckup L, Crandall KA (2008) Global diversity of crabs (Aeglidae: Anomura: Decapoda) in freshwater. Hydrobiologia 595: 267-273.

Boss Jr H, Silva-Castiglioni D, Schacht K, Buckup L, Bond-Buckup G (2006) O crescimento de Aegla jarai Bond-Buckup e Buckup (Crustacea, Anomura, Aeglidae). Revista Brasileira de Zoologia 23: 490-496. doi: 10.1590/S0101-81752006000200024

Bueno AAP, Bond-Buckup G (2000) Dinâmica populacional de Aegla platensis Schmitt (Crustacea, Decapoda, Aeglidae). Revista Brasileira de Zoologia 17: 43-49. doi: 10.1590/ S0101-81752000000100005

Bueno AAP, Bond-Buckup G, Buckup L (2000) Crescimento de Aegla platensis Schmitt em ambiente natural (Crustacea, Decapoda, Aeglidae). Revista Brasileira de Zoologia 17: 51-60. doi: 10.1590/S0101-81752000000100006

Bueno SLS, SHIMIZu RM (2008) Reproductive biology and functional maturity infemales of Aegla franca (Decapoda: Anomura: Aeglidae). Journal of Crustacean Biology 28: 652-662.

Bueno SLS, Shimizu RM (2009) Allometric growth, sexual maturity, and adult male chelae dimorphism in Aegla franca (Decapoda: Anomura: Aeglidae). Journal of Crustacean Biology 29: 317-328.

Bueno SLS, Takano BF, Cohen FPA, Moraes JCB, Chiquetto-Machado PI, Vieira LCM, Shimizu RM (2014) Fluctuations in the population size of the highly endemic Aegla perobae (Decapoda: Anomura: Aeglidae) caused by a disturbance event. Journal of Crustacean Biology 34: 165-173.

Chiquetto-Machado PI, Vieira LCM, Shimizu RM, Bueno SLS (2015) Life cycle of the freshwater anomuran Aegla schmitti Hobbs, 1978 (Decapoda: Anomura: Aeglidae) from southeastern Brazil. Journal of Crustacean Biology 36: 39-45.

Cohen FPA, Takano BF, Shimizu RM, Bueno SLS (2011) Life Cycle and Population Structure of Aegla paulensis (Decapoda: Anomura: Aeglidae). Journal of Crustacean Biology 31: 389-395.

Colpo KD, Ribeiro LD, Santos S (2005) Population biology of the freshwater Anomura Aegla longirostri (Aeglidae) from South Brazilian streams. Journal of Crustacean Biology 25: 495-499.

Copatti CE, Machado JVV, Trevisan A (2015) Morphological variation in the sexual maturity of three sympatric aeglids in a river in southern Brazil. Journal of Crustacean Biology 35: 59-67. 
Copatti CE, Zanini LG, Valente A (2009) Ictiofauna da microbacia do rio Jaguari - Jaguari/RS. Biota Neotropica 9: 179-186.

Dalosto MM, Palaoro AV, Oliveira D de, Samuelsson E, Santos S (2014) Population biology of Aegla platensis (Decapoda: Anomura: Aeglidae) in a tributary of the Uruguay River, state of Rio Grande do Sul, Brazil. Zoologia 31: 215-222. doi: 10.1590/S1984-46702014000300002

Da Silva AR, Wolf MR, Castilho AL (2016) Reproduction, growth and longevity of the endemic South American crab Aegla marginata (Decapoda: Anomura: Aeglidae). Invertebrate Reproduction \& Development 60: 59-72.

Fernandes CS, Bueno SLS, Bichuette ME (2013) Distribution of cave-dwelling Aegla spp. (Decapoda: Anomura: Aeglidae) from the Alto Ribeira Karstic area in southeastern Brazil based on geomorphological evidence. Journal of Crustacean Biology 33: 567-575.

Grabowski RC, SANTos S, CASTILHo AL (2013) Reproductive ecology and size of sexual maturity in the anomuran crab Aegla parana (Decapoda: Aeglidae). Journal of Crustacean Biology 33: 332-338.

Hartnoll RG (1974) Variation in growth patterns between some secondary sexual characters in crabs. Crustaceana 27: 131-136.

Hartnoll RG (1982) Growth, p. 11-196. In: Buiss DE (Ed.) The biology of Crustacea: embryology, morphology and genetics. New York, Academic, vol. 2.

Hartnoll RG (2001) Growth in Crustacea: Twenty years on. Hydrobiologia 449: 111-122.

Lopez MT (1965) Estudios biológicos en Aegla odebrechtii paulensis, Schmitt (Crustacea, Decapoda, Anomura). Boletim de Zoologia da Faculdade de Filosofia, Ciências e Letras 25: 301-314.

Macdonald PDM (1987) The analysis of length-frequency distributions, p. 371-384. In: Summerfelt RC, Hall G (Eds.) Age and growth of fish. Ames, Iowa State University Press.

Margalef R (1977) Ecologia. Barcelona, Ediciones Omega.

Noro CK, Buckup L (2003) O crescimento de Aegla leptodactyla Buckup \& Rossi (Crustacea, Anomura, Aeglidae). Revista Brasileira de Zoologia 20: 191-198. doi: 10.1590/S010181752003000200003

Oliveira D DE, SANTos S (2011) Maturidade sexual morfológica de Aegla platensis (Crustacea, Decapoda, Anomura) no Lajeado Bonito, norte do estado do Rio Grande do Sul, Brasil. Iheringia, Série Zoologia, 101: 127-130. doi: 10.1590/S0073-47212011000100018

Palaoro AV, Dalosto MM, Costa JR, Santos S (2014) Freshwater decapod (Aegla longirostri) uses a mixed assessment strategy to resolve contests. Animal Behaviour 95: 71-79.

PezzuTo PR (1993) REGRANS: a "basic" program for an extensive analysis of relative growth. Atlântica 15: 91-105.

Rodrigues W, Hebling NJ (1978) Estudos biológicos em Aegla perobae Hebling e Rodrigues, 1977 (Decapoda, Anomura). Revista Brasileira de Biologia 38: 383-390.

Santos S, Jara CG, Bartholomei-Santos ML, Pérez-Losada M, CranDALL KA (2013) New species and record of the genus Aegla
Leach, 1820 (Crustacea, Anomura, Aeglidae) from the West-Central region of Rio Grande do Sul state, Brazil. Nauplius 21: 211-223.

Silva-Castiglioni D, Barcelos DF, Santos S (2006) O crescimento de Aegla longirostri Bond-Buckup \& Buckup (Crustacea, Anomura, Aeglidae). Revista Brasileira de Zoologia 23: 408-413. doi: 10.1590/S0101-81752006000200015

Silva-Gonçalves R, Bond-Buckup G, Buckup L (2009) Crescimento de Aegla itacolomiensis (Crustacea, Decapoda) em um arroio da Mata Atlântica no sul do Brasil. Iheringia, Série Zoologia, 99: 397-402. doi: 10.1590/S0073-47212009000400009

Silva-Gonçalves R, SiLVA-Castiglioni D, Bond-Buckup G (2006) Ecologia populacional de Aegla franciscana (Crustacea, Decapoda, Anomura) em São Francisco de Paula, RS, Brasil. Iheringia, Série Zoologia, 96: 109-114. doi: 10.1590/S0073-47212006000100019

Siqueira AF, Palaoro V, Santos S (2013) Mate preference in the neotropical freshwater crab Aegla longirostri (Decapoda: Anomura): does the size matter? Marine and Freshwater Behaviour and Physiology 46: 219-227.

SpIEgel MR (1979) Estatística. São Paulo, McGraw-Hill.

SoKal RR, Rohlf JF (1979) Biometry. New York, W.H. Freeman, $3^{\text {rd }}$ ed.

Sokolowicz CC, Bond-Buckup G, Buckup L (2006) Dynamics of gonadal development of Aegla platensis Schmitt (Decapoda, Anomura, Aeglidae). Revista Brasileira de Zoologia 23: 1153-1158. doi: 10.1590/S0101-81752006000400023

Sokolowicz CC, López-Greco LS, Gonçalves R, Bond-Buckup G (2007) The gonads of Aegla platensis Schmitt (Decapoda, Anomura, Aeglidae): a macroscopic and histological perspective. Acta Zoologica (Stockholm) 88: 71-79.

SwiEch-Ayoub BP, MasunaRi S (2001) Flutuações temporal e espacial de abundância e composição de tamanho de Aegla castro Schmitt (Crustacea, Anomura, Aeglidae) no Buraco do Padre, Ponta Grossa, Paraná, Brasil. Revista Brasileira de Zoologia 18: 1003-1017. doi: 10.1590/S0101-81752001000300032

Teodósio EAO, Masunari S (2009) Estrutura populacional de Aegla schmitti (Crustacea: Anomura: Aeglidae) nos reservatórios dos Mananciais da Serra, Piraquara, Paraná, Brasil. Zoologia 26: 19-24. doi: 10.1590/S1984-46702009000100004

Trevisan A, Santos S (2011) Crescimento de Aegla manuinflata (Decapoda, Anomura, Aeglidae) em ambiente natural. Iheringia, Série Zoologia, 101: 336-342. doi: 10.1590/S007347212011000300008

Trevisan A, SANTos S (2012) Morphological sexual maturity, sexual dimorphism and heterochely in Aegla manuinflata (Anomura). Journal of Crustacean Biology 32: 519-527.

Trevisan A, Santos S (2014) Population dynamics of Aegla manuinflata Bond-Buckup and Santos 2009 (Decapoda: Aeglidae), an threatened species. Acta Limnologica Brasileira 26: 154-162.

Trevisan A, Marochi MZ, Costa M, Santos S, Masunari S (2012) Sexual dimorphism in Aegla marginata (Decapoda: Anomura). Nauplius 20: 75-86.

Tudge CC (2003) Endemic and enigmatic: the reproductive biology of Aegla (Crustacea: Anomura: Aeglidae) with observations 
on sperm structure. Memoirs of Museum Victoria 60: 63-70. Valenti WC, Mello JTC, Lobão VL (1987) O crescimento de Macrobrachium acanthurus (Wiegmann, 1863) do Rio Ribeira de Iguape (Crustacea, Decapoda, Palaemoonidae). Revista Brasileira de Biologia 47: 349-355.

Viau VE, Greco LSL, Bond-Buckup G, Rodríguez EM (2006) Size at the onset of sexual maturity in the anomuran crab, Aegla uruguayana (Aeglidae). Acta Zoologica 87: 253-264.

ZAR JH (1996) Biostatistical analysis. Upper Sadle River, Prentice-Hall.
Submitted: 22 January 2016

Received in revised form: 4 April 2016

Accepted: 8 May 2016

Editorial responsibility: Paulo da Cunha Lana

Author Contributions: CEC, RPL, AT and SS participated equally in the preparation of this article.

Competing Interests: The authors have declared that no competing interests exist. 